\title{
Türkiye'de Öğretmen Yeterlikleri ve Teknolojik Pedagojik Alan Bilgisi Araştırmaları
}

\author{
Ahmet SAYKAL \\ Amasya Üniversitesi \\ saykalahmet05@gmail.com \\ Şafak ULUÇINAR SAĞIR \\ Amasya Üniversitesi \\ safak.ulucinar@amasya.edu.tr
}

Gönderilme Tarihi: 31/01/2021

Kabul Tarihi: 30/07/2021

Yayınlanma Tarihi: 31/07/2021

\begin{tabular}{|c|c|}
\hline Makale Bilgileri & ÖZET \\
\hline $\begin{array}{l}\text { Anahtar Kelimeler: } \\
\text { Öğretmen } \\
\text { Yeterlikleri, } \\
\text { Teknoloji, } \\
\text { Teknolojik } \\
\text { Pedagojik Alan } \\
\text { Bilgisi, } \\
\text { Yeterlik }\end{array}$ & $\begin{array}{l}\text { Bu araştırmada Türkiye'de } 2000-2020 \text { yılları arasında öğretmen yeterlikleri ve } \\
\text { teknolojik pedagojik alan bilgisi konuları üzerine yayınlanmış olan çalışmaların } \\
\text { yayın yılı, yayın türü, örneklem grubu, konu, branş, yöntem ve veri toplama } \\
\text { araçlarına göre incelemelerinin yapılması amaçlanmıştır. Araştırmada } \\
\text { doküman analizi yöntemi kullanılmıştır. Verilere “Google Akademik, YÖK } \\
\text { Ulusal Tez Merkezi, ULAKBIM, Asos Index ve YÖK Akademik" veri } \\
\text { tabanlarından anahtar kelimelerle tarama yapllarak ulaşılmıştır. Araştırmanın } \\
\text { bulguları kapsamında öğretmen yeterlikleri konusunda; en fazla çalışmanın } \\
2015 \text { yılında yapıldığı görülmüştür. Örneklem grubu olarakta en fazla öğretmen } \\
\text { ve öğretmen adayları ile çalışmalar yapılmıştır. Çalışmalar makale ve bildiri } \\
\text { türünde yoğunlaşmıştır. Yapılan bu çalışmalarda öğretmen yeterliği, öğretmen } \\
\text { mesleki yeterlikleri ve öğretmen yeterlik algılarının çoğunlukla çalışıldığ1 } \\
\text { görülmüştür. Araştırmalarda genelde nicel yöntem kullanılmış olup, tarama } \\
\text { deseni kullanılmıştır. Veri toplama aracı olarak ölçek ve anketler çoğunlukta } \\
\text { kullanılmıştır. Teknolojik pedagojik alan bilgisi (TPAB) çalışmalarının ise en } \\
\text { fazla } 2018 \text { yılında yapıldı̆ğ görülmüştür. Yapılan çalışmalar makale ve bildiri } \\
\text { türünde yoğunlaşmıştır. Örneklem grubu olarak yüksek oranda öğretmen } \\
\text { adayları ve öğretmenler seçilmiştir. Yapılan bu çalışmalarda genellikle TPAB’ne } \\
\text { ilişkin yeterlikler, TPAB düzeyleri, TPAB sınıf içi uygulamalar, TPAB üzerine } \\
\text { algı yönünde çalışmalar yapılmıştır. TPAB yönelik çalışılan konuların büyük } \\
\text { çoğunluğunun öğretmen yeterlikleri kapsamında olduğu görülmüştür. } \\
\text { Araştırmalarda genelde nicel yöntem kullanılmış olup, tarama deseni } \\
\text { kullanılmıştır. Veri toplama aracı olarak ölçek ve anketler çoğunlukta } \\
\text { kullanılmıştır. }\end{array}$ \\
\hline
\end{tabular}

Saykal, A., \& Uluçınar Sağır, Ş. (2021). Türkiye'de öğretmen yeterlikleri ve teknolojik pedagojik alan bilgisi araştırmaları. Gazi Ĕ̆itim Bilimleri Dergisi, 7(2), 115-137. https://dx.doi.org/10.30855/gjes.2021.07.02.001

Dergi Web Sayfası: http://dergipark.gov.tr/gebd 


\section{Teacher Competences and Technological Pedagogical Content Knowledge Researches in Turkey}

\begin{tabular}{ll}
\hline \hline Article Info & ABSTRACT \\
\hline Keywords: & $\begin{array}{l}\text { The years of 2000-2020 in Turkey in this study between teacher qualifications } \\
\text { and technological pedagogical content knowledge in the publication of studies } \\
\text { Teacher } \\
\text { Technotences, }\end{array}$ \\
Technological & to make examination of according to the methods and data collection. It was \\
pedagogical field & designed as a document analysis method. The data were obtained by searching \\
knowledge, & with keywords from databases such as “Google Academic, YÖK National Thesis \\
Competence & Centre, (ULAKBIM), ASOS Index and YÖK academic. Within the scope of the \\
& research findings, it was observed that the most studies on teacher competences \\
& were conducted in 2015. As the sample group, studies were mostly conducted \\
& with teachers and pre-service teachers. Studies have focused on article and \\
presentation type. In these studies, it was observed that perceptions of teacher \\
competences, teacher Professional competences were mostly studied. Generally, \\
quantitative method was used in researches, and scanning design was used. \\
Scales and questionnaires were used as data collection tools. In addition, it was \\
observed that technological pedagogical content knowledge (TPACK) was \\
mostly carried out in 2018. Studies also have focused on article and bulletin \\
types. As the sample group, pre-service teachers and teachers were mostly \\
selected. In these studies, generally TPACK competencies, TPACK levels, \\
TPACK classroom applications, TPACK perception studies were carried out. \\
Generally, quantitative method was used in researches, and scanning design \\
was used. Scales and questionnaires were used as data collection tools. \\
\hline
\end{tabular}

\section{GİRIŞ}

Son yıllarda gelişen teknolojinin beraberinde getirdiği sosyolojik değişimler toplumların ihtiyaçlarını ve gereksinimlerini değiştirmiştir. Bu durum bireylerin sahip olması gereken niteliklerde ve alacakları eğitimde etkili olmuştur. Eğitim toplumsal değerleri kuşaktan kuşağa aktararak sosyalleşmeyi gerçekleştiren, bireyin becerilerinin ve yeteneklerinin keşfedilerek geliştirip bireye kişilik kazandıran, bireyin bir meslek sahibi olabilmesi için gerek duyduğu bilgi, beceri ve tutumları kazandırarak bireyi meslek sahibi yapmak gibi birçok önemli görevi yerine getirir (Başbay ve Bektaş, 2010). Ülkemizde de eğitim sisteminin çağa ayak uydurabilmesi için dünyadaki eğitim sistemlerine paralel olarak düzenlenmesi hedeflenmektedir. Bu düzenleme ile 21. yüzyıl becerileri olarak karşımıza çıkan eleştirel düşünme ve problem çözme, etkili iletişim, kültürel farklılıklara saygı, işbirlikli öğrenme gibi becerileri kazandırılmış bireyler yetiştirmek amaçlanmaktadır. Bu becerilerin kazandırılmasında öğretim programlarının yapılandırılması ve bu öğretim programlarını uygulayacak olan öğretmenlerin bu becerileri kazandırabilecek nitelikte ve yeterlikte olması gerekmektedir (Gürültü, Aslan ve Alcı,2018). Bütün toplumlarda tarih süresince öğretmenlik mesleği bilgiyi kuşaktan kuşağa aktardığı için bir köprü vazifesi görmüş ve en saygın mesleklerden biri olmuştur (Güven, 2010). Bu derece hayati görevi yerine getiren öğretmenlerin nitelikleri ve yeterlikleri büyük öneme sahiptir. Öğretmenlerin eğitimin 
planlayıcısı, başlatıcısı, uygulayıcısı ve değerlendiricisi olduklarından niteliklerinin de çok iyi olması gerekmektedir (Gündoğdu Aytaçlı, Aydoğan ve Yıldırım, 2015). Yüksek nitelikli ve yeterlikte öğretmenlere sahip olmak eğitim alanındaki yapılacak değişiklikler için en önemli şarttır.

Günümüzde eğitimin geldiği son noktaya bakıldığında öğretmenlere mesleki anlamda yeni sorumluluklar ve görevler getirdiği görülmektedir. Öğretmenlerin yetiştirdikleri bireylerin sorumluluğunu taşıyabilecek yüksek yeterlikler gerektiren bir meslek olduğu bilincinde olması gerekir. Bu sebeple öğretmenlerin kendilerini sürekli gelişime açık tutmaları gerekmektedir (Atmaca, 2017).

Öğretmen yeterliği; öğretmenlerin mesleklerini en iyi biçimde yani etkili ve verimli bir şekilde yapabilmeleri için sahip olmalarn gereken bilgi beceri ve tutumlar olarak tanımlanabilir (Milli Eğitim Bakanlığı, 2017). Eğitim alanında planlanan bir programın hedefe ulaşabilmesi için, programı eğitim ve öğrenme ortamında uygulayacak olan öğretmenlerin bu programı uygulayabilecek yeterlikte olması gerekir (Tosuntaş 2020). Öğretmen, öğrenme ortamını öğrencilerin farklılıklarına göre düzenleyebilen, öğrenci farklılıklarını dikkate alan ve öğrencilere rehberlik edebilen, ulaşmak istediği hedeflere elindeki imkanları en verimli şekilde kullanarak ulaşacak yeterliliklere sahip olmalıdır (Pantic ve Wubbels 2010).

Öğretmen yeterliliklerine bakıldığında bir öğretmende bulunması gereken yeterlikler şu şekilde olabilir:

-Olumlu bir öğrenme iklimi oluşturmalı,

-Öğrencilerin farklı öğrenme biçimlerini dikkate almalı,

-Yaratıcı ve analitik düşünmeye önem vermeli,

-Öğrencilerin kendini tanımalarını ve geliştirmelerine olanak sağlamalı,

-İyi bir iletişim becerisine sahip olmall,

-Eğitim ve öğretim planını etkin bir şekilde yapabilmeli,

-İyi bir entelektüel bilgiye sahip olmall,

-Gerekli mesleki bilgi ve beceriye sahip olmalıdır (MEB, 2017).

Ülkemizde öğretmen yeterliliği konusunda ilk resmi çalışmalar 1999 yılında başlamış olup, 2002 yılında yürürlüğe giren “öğretmen yeterlikleri” belgesi hazırlanmıştır. Daha sonraki yıllarda değişen şartlar gereği Öğretmen Yetiştirme ve Eğitimi Genel Müdürlüğü ile Eğitim Araştırma ve Geliştirme Daire Başkanlığı çok sayıda ülkedeki öğretmen yeterliği kapsamındaki dokümanları incelemiş ve ülkemizdeki öğretmen yeterliliğinin Avrupa Birliği ülkeleriyle paralel olacak biçimde tasarlamıştır (MEB, 2017). Bu çalışmalara katılan ulusal ve uluslararası uzmanlar, öğretmenler, akademisyenler ve çok sayıda katılımcının bulunduğu çalıştaylar ile öğretmen yeterliği konusunda 6 ana yeterlik alanı, bu yeterlik alanlarına yönelik 31 alt yeterlik alanı ve 233 
performans göstergesinden oluşan “Öğretmenlik Mesleği Genel Yeterlikleri” belirlenmiş ve 2006 yılında yürürlüğe girmiştir (Betaş, Can ve Çalıkoğlu, 2019).

Öğretmenlik Mesleği Genel Yeterliliklerinin eğitim alanındaki değişimlere ve eğitim sistemimizdeki yeniliklere uygun biçimde olabilmesi için güncellenme ihtiyacı ortaya çıkmış ve Yüksek Öğretim Kurumu, Ölçme, Seçme ve Yerleştirme Merkezi, Talim Terbiye Kurulu, Mesleki Yeterlik Kurumu ve birçok paydaşın katılımı ile işbirliği içinde öğretmenlik mesleği genel yeterlikleri 2017 yılında güncellenmiştir (Tuğluk ve Kürkmen, 2018). Bu güncelleme ile; öğretmenlik mesleği genel yeterlikleri mesleki bilgi, mesleki beceri ve tutum ve değerler olmak üzere üç yeterlik alanında toplanmıştır. Mesleki bilgi yeterlik alanında alan bilgisi, alan eğitimi bilgisi ve mevzuat bilgisi alt yeterlilik alanları oluşturulmuştur. Bu yeterlik alanına ait 16 gösterge belirlenmiştir. Mesleki beceri yeterlik alanında ise eğitim öğretimi planlama, öğrenme ortamları oluşturma, öğretme ve öğrenme sürecini yönetme, ölçme ve değerlendirme alt yeterlik alanları vardır. Bu yeterlik alanına ait 28 gösterge belirlenmiştir. Tutum ve değerleri yeterlik alanına bakıldığında milli manevi ve evrensel değerler, öğrenciye yaklaşım, iletişim ve işbirliği, kişisel ve mesleki gelişim alt yeterlilik alanları vardır. Bu yeterlik alanına ait 21 gösterge belirlenmiştir.

Milli Eğitim Bakanlığı paydaş kurumlar ile yapmış olduğu öğretmen yeterlikleri çalışması ile öğretmen yetiştirmeye yönelik programlarının düzenlenmesi, öğretmen istihdamı adaylık ve yetiştirme süreçleri, öğretmenin öz değerlendirme yapması, performans değerlendirme kariyer gelişimi ve ödüllendirme, hizmet içi eğitim programlarının planlanması ve sürekli mesleki gelişim alanlarında bütün paydaşların referans alabileceği bir belgeyi oluşturmuştur (MEB, 2017).

Öğretmenlerimizin mesleki bilgi alanında yeterli olabilmeleri için alan bilgilerinin ileri düzeyde olması gerekir ve alanlarına ait bilgilerini öğrencilere aktarabilecek pedagojik alan bilgisine hakim olmalıdır (Azgın ve Şenler, 2018). Shulman (1986) tarafından ortaya konulan pedagojik alan bilgisi çerçevesine göre bir öğretmenin öncelikle iyi bir alan bilgisine ve bu bilgiyi en iyi şekilde aktarabilecek pedagoji bilgisine sahip olması gerektiği yönündedir. Fakat son yıllarda yaşanan teknolojik değişimler ve gelişmeler çerçevesinde öğretmenin eğitim öğretim sürecini verimli bir şekilde yürütülebilmesi için iyi bir teknoloji kullanım bilgisine ve becerisine de sahip olması gerekmektedir (Garba, Byabazaire ve Butshami, 2015).

Son yıllarda teknolojinin eğitimde kullanılabilmesi için okullarımızda fiziki anlamda iyileştirmeler yapılmış; bilgisayar, akıllı tahta, projeksiyon cihazı, internet gibi teknolojik imkanlar sağlanmıştır. Fakat eğitimin en önemli unsuru öğretmenlerdir. Öğretmenin öğrenme ortamında sergileyeceği performansı diğer tüm eğitim öğretim unsurlarından en önemlisidir (Voogt, Fisser, Pareja-Roblin, Tondeur ve Braak, 2013). Ne kadar teknolojik imkanlarla hazırlanmış sınıflar ve eğitim alanları oluştursak da bunu kullanacak olan öğretmen ve öğrencilerin bu alt yapıya sahip olması gerekmektedir (Öztürk, 2013). Öğretmenlerimizin sağlanan bu teknolojik alt yapıyı sadece internetten araştırma yapmak, yıllık ve günlük plan 
hazırlamak, soru hazırlamak, video izletmek gibi amaçlarla kullanmaları eğitim ve öğretim açısından teknolojinin verimli kullanıldığı anlamına gelmemektedir (Yanpar, Tokmak, Özgelen ve İncikabı, 2013). Öğretmenlerimizin okullarımızda sağlanan bu teknolojiyi eğitim-öğretim sürecinde öğrencilerin derse etkin katılımını artırmak, öğrencilerin derslere motivasyonunu artırmak, öğrenilmesi zor konuları somutlaştırarak kolaylaştırmak ve öğrenilenlerin kalıcılığına sağlamak için kullanmaları gerekmektedir (Bağdiken ve Akgündüz, 2018). Öğretmenlerin bu derece verimli olabilecek teknolojiyi eğitimde kullanmaları için 1986 yılında Shulman'ın ortaya koyduğu pedagojik alan bilgisinin yanına Koehler ve Mishra (2009) teknoloji bilgisini de ekleyerek "teknolojik pedagojik alan bilgisi" kavramı ortaya çıkmıştır.

Teknolojik pedagojik alan bilgisinin üç ana bileşeni vardır. Bu bileşenler teknoloji, pedagoji ve içeriktir. Bu bileşenlerden içerik ve pedagojinin birleşimi ile pedagojik alan bilgisi, pedagoji ve teknolojinin birleşmesi ile teknolojik pedagojik bilgi, teknoloji ve içeriğin birleşmesi ile teknolojik alan bilgisi ortaya çıkmaktadır. Üç ana bileşenin kesişimi ile de teknolojik pedagojik alan bilgisi ortaya çıkmaktadır (Azgın ve Şenler 2018).

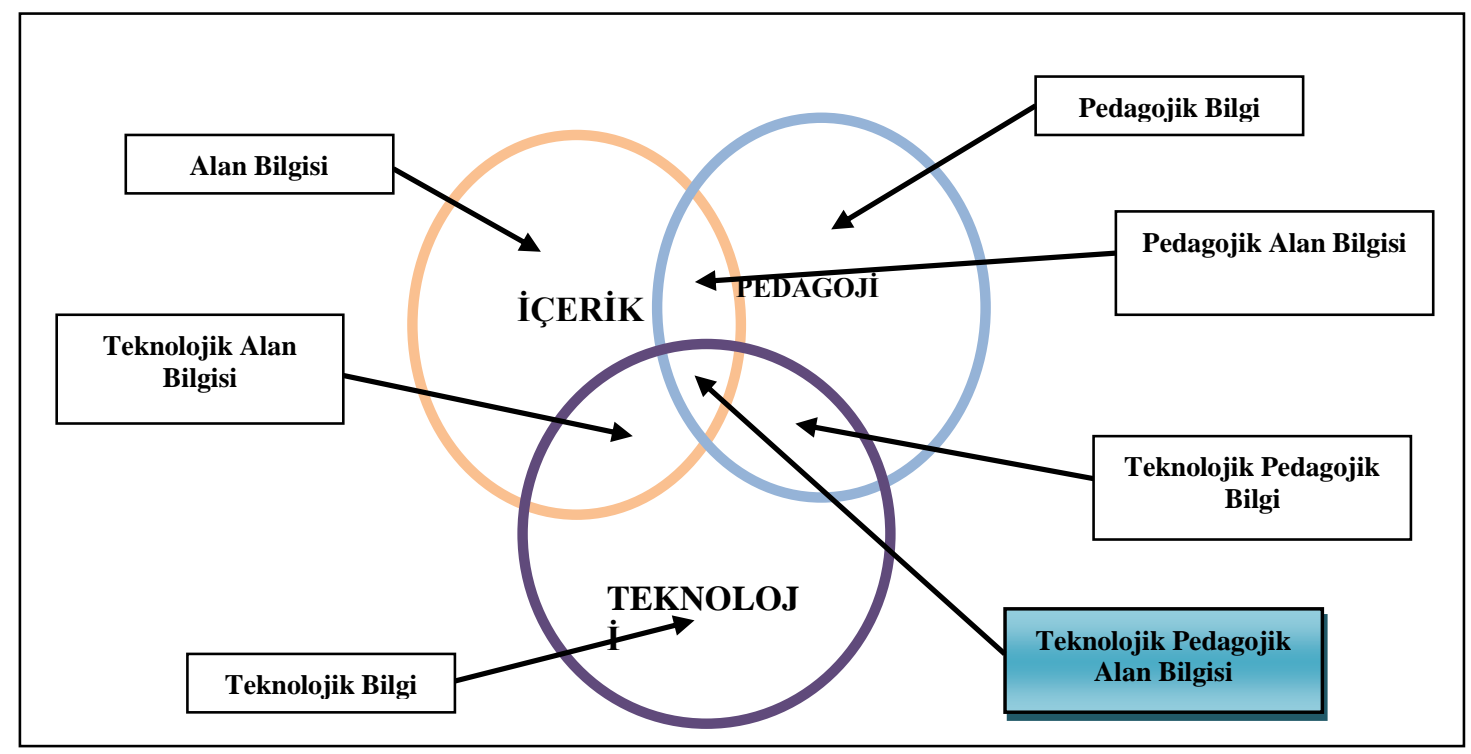

Şekil 1. TPAB çerçevesi ve bilgi bileşenleri (Koehler ve Mishra, 2009).

Alan bilgisi, öğretimi gerçekleştirilecek olan konu ve kazanımlardır (Azgın ve Şenler, 2018). Pedagojik bilgi; öğretilecek konu veya kazanımın hangi yöntem teknik ve strateji ile öğretileceği bilgisidir, neyin öğretileceğinden çok nasıl öğretileceği ile ilgilidir. Öğretilmesi planlanan hedeflere ulaşabilmek için hedef kitlenin niteliklerini de dikkate alarak etkili ve verimli olabilecek öğrenme süreci ve öğrenme ortamı hazırlayabilme bilgisidir (Baran ve Canbazoğlu Bilici, 2015). Teknolojik bilgi; öğretmenin en basit teknolojik araçlardan en üst düzey teknolojik araç ve gereçlere yönelik bilgisidir (Karakuyu ve Karakuyu, 2016). Teknolojik alan bilgisi; öğretimi planlanan konu veya kazanımın hangi teknolojik araç ve gereçlerle öğretilmesinin uygun olacağı ve bu teknolojik araç gerecin öğretimde avantaj ve dezavantajlarının neler 
olabileceği hakkındaki bilgidir (Kaleli Yılmaz, 2018). Pedagojik alan bilgisi; öğretimi planlanan konu veya kazanımın nasıl öğretilmesi uygun olacağı yönündeki bilgi iken teknolojik pedagojik bilgi, öğretim sürecinde teknolojik araç gereçlerin nasıl kullanılacağı ve eğitim sürecini nasıl etkileyeceği hakkındaki bilgidir. Teknolojik pedagojik alan bilgisi, öğretmenlerin öğretim yaparken pedagojik alan bilgisinin yanında teknolojiyi etkili bir şekilde kullanarak teknolojiyi öğretimleri ile uygun ve etkili olarak bütünleştirmesidir (Mishra ve Koehler 2006).

Teknolojik pedagojik alan bilgisi eğitim öğretim sürecinde öğretmenlerin teknolojik bilgi, pedagojik bilgi ve alan bilgilerini bütünleştirerek, teknolojinin eğitim öğretim sürecine entegrasyonunu sağlayarak, eğitim öğretim yapmasını planlayan bir modeldir. Öğrencilere öğretimi yapılacak konuların daha iyi yapılandırabilmesi için seçilen öğretimsel yöntem ve tekniklerin teknoloji ile entegre edilerek kullanılmasını ifade etmektedir. Bir başka ifade ile teknolojik pedagojik alan bilgisi teknolojinin sınıf içindeki öğretme ve öğrenme süreçlerine sentezlenmesidir (Çoban, Akpınar, Baran, Sağlam, Özcan ve Kahyaoğlu, 2016).

Son yıllarda hayatımızın her alanda olduğu gibi eğitim öğretim alanında da teknolojinin yaygın kullanılması gerekliliğini görmekteyiz. Ülkemizde son yıllardaki teknolojik alt yapı çalışmaları ile (internet bağlantısı, bilgisayar, akıllı tahta vb.) eğitim-öğretim ortamlarına teknolojik imkanlar sağlanmıştır. Eğitim öğretimin en önemli unsuru olan öğretmenlerin bu teknolojik imkanları kullanmaları çağın gereği olmuştur (Kula, 2015). Öğretmenlik mesleği genel yeterliklerine bakıldığında alan bilgisi ve pedagojik bilginin yanında eğitim öğretimi planlamak, etkili öğrenme ortamları oluşturmak, öğretme öğrenme sürecini yönetme, ölçme değerlendirme gibi alanlarda kişisel ve mesleki gelişimini sağlayan öğretmenlerin yeterli ve etkili olacağı vurgulanmaktadır (MEB, 2017). Çağın gereği olan teknolojiyi eğitim öğretim ortamlarında etkili ve verimli kullanarak eğitim öğretimi planlayan, etkili öğrenme ortamları oluşturarak, öğrencilerin etkin katılımını sağlayan, ilgi ve motivasyonunu artırarak kalıcı öğrenmeyi sağlayacak şekilde teknolojiyi öğrenme ortamına entegre edecek yüksek TPAB'ne sahip olmak öğretmen yeterliliğinin temeli haline gelmiştir (Kabakc1, 2011). Ülkemizde öğretmen mesleki yeterlikleri ile ilgili ilk çalışmaların yapıldığı 1999'dan itibaren bu konuya yönelik yapılan çalışmaların ve TPAB'la ilgili araştırmalardaki eğilimin belirlenmesi genel durumun tespiti ve gelecekteki araştırmalara yön vermesi açısından önemli görülmüştür. Teknolojl araçaların tüm hayatımıza ve eğitim öğretim ortamlarına girmesiyle birlikte öğretmen yeterlilikleri kapsamında teknolojinin öğretmenler tarafından kullanımı ve eğitim öğretim ortamlarına entegre ederek kullanabilmeleride önemlidir.

\section{Araştırmanın Amacı}

Bu araştırmanın amacı; 2000-2020 yılları arasında öğretmenlerin mesleki yeterlikleri ve teknolojik pedagojik alan bilgisi alanları üzerine yazılmış çalışmaların incelenmesidir. Son 
yıllarda eğitim öğretim ortamları teknolojik araç gereçler ile buluşmuştur. Öğretmenlerin bu teknolojik araç gereçleri eğitim öğretim sürecine sentezleyerek kullanmaları gerekir. Öğretmenlerin teknolojik pedagojik alan bilgileri mesleki yeterlilik açısından önemlidir. Bu amaçla 2000-2020 yılları arasında öğretmenlerin mesleki yeterlikleri ve teknolojik pedagojik alan bilgisi üzerine ulusal ve uluslararası yayınlarda yayınlanmış makale, yüksek lisans ve doktora tezi ve bildiriler incelenmiş ve bu kapsamda aşağıdaki sorulara cevap aranmıştır.

1. Öğretmenlerin mesleki yeterlik ve TPAB'ları üzerine yayınlanmış çalışmaların konu dağılımları nasıldır?

2. Öğretmenlerin mesleki yeterlik ve TPAB'ları üzerine yayınlanmış çalışmaların çalışma grubu nedir?

3. Öğretmenlerin mesleki yeterlik ve TPAB'ları üzerine yayınlanmış çalışmaların branşlara göre dağılımı nasıldır?

4. Öğretmenlerin mesleki yeterlik ve TPAB'ları üzerine yayınlanmış çalışmaların yıllara göre dağılımı nasıldır?

5. Öğretmenlerin mesleki yeterlik ve TPAB'ları üzerine yayınlanmış çalışmaların yayın türüne göre dağılımı nasıldır?

6. Öğretmenlerin mesleki yeterlik ve TPAB'ları üzerine yayınlanmış çalışmaların kullanılan yöntemlerine göre dağılımı nasıldır?

7. Öğretmenlerin mesleki yeterlik ve TPAB'ları üzerine yayınlanmış çalışmaların veri toplama araçlarına göre dağılımı nasıldır?

\section{YÖNTEM}

\section{Araştırmanın Modeli}

Bu araştırmada 2000-2020 yılları arasında öğretmen mesleki yeterlikleri ve teknolojik pedagojik alan bilgileri üzerine yapılmış çalışmaların incelenmesi amaçlandığından nitel araştırma yaklaşımı çerçevesinde doküman analizi yöntemi kullanılmıştır.

Doküman analizi yöntemi ile araştırması yapılan konu ile ilgili olarak, yazılı belgelerin sistematik bir şekilde, belirlenen kriterlere göre araştırması yapılır (Yıldırım ve Şimşek, 2016).

\section{Evren ve Örneklem}

Araştırmanın çalı̧̧ma grubunu 2000-2020 yılları arasında öğretmenlerin mesleki yeterlikleri ve teknolojik pedagojik alan bilgisi üzerine çalışılmış toplam 525 araştırma (makale, bildiri, yüksek lisans ve doktora tezleri) oluşturmaktadır.

\section{Verilerin Toplanması ve Analizi}

Araştırmada Türkiye'de 2000-2020 yılları arasında öğretmen mesleki yeterlikleri ve teknolojik pedagojik alan bilgileri üzerine yayınlanmış çalışmalar "Google Akademik, YÖK 
Ulusal Tez Merkezi, ULAKBİM, Asos Index ve YÖK Akademik" veri tabanlarından öğretmen mesleki yeterliği, öğretmen yeterliği, pedagojik bilgi ve teknolojik pedagojik alan bilgisi anahtar kelimeleri kullanılarak taranmıştır. Aralık 2020 tarihi ve açık erişim kolaylığı sınırlaması ile seçilen veri tabanlarından ulaşılan dokümanların çalışma konularına, çalışma gruplarına, branşlara, yayın türlerine, yöntemlerine ve veri toplama araçlarına göre incelemesi yapılmıştır. Yapılan taramalar neticesinde öğretmen mesleki yeterlikleri alanında 208 çalışmaya ulaşılmıştır. Teknolojik pedagojik alan bilgisi kapsamında 317 çalışmaya ulaşılmış ve incelemeleri yapılmıştır. Doktora ve yüksek lisans tezlerinden üretilen makaleler çalışmaya dahil edildiği için bu çalışmalar çalışma kapsamına alınmamıştır. Verilerin betimsel analizi yapılmış, frekans ve yüzde tabloları ve grafikler halinde sonuçlar verilmiştir.

\section{BULGULAR}

$\mathrm{Bu}$ bölümde incelenen çalışmalar öğretmen mesleki yeterliklerine ilişkin veriler ve teknolojik pedagojik alan bilgisine ilişkin veriler olmak üzere iki başlıkta verilmiştir.

\section{Öğretmen Mesleki Yeterliklerine İlişkin Veriler}

2000-2020 yılları arasında yayınlanan öğretmen mesleki yeterlilik çalışmalarının yayınlandıklara yıllara göre analizi:

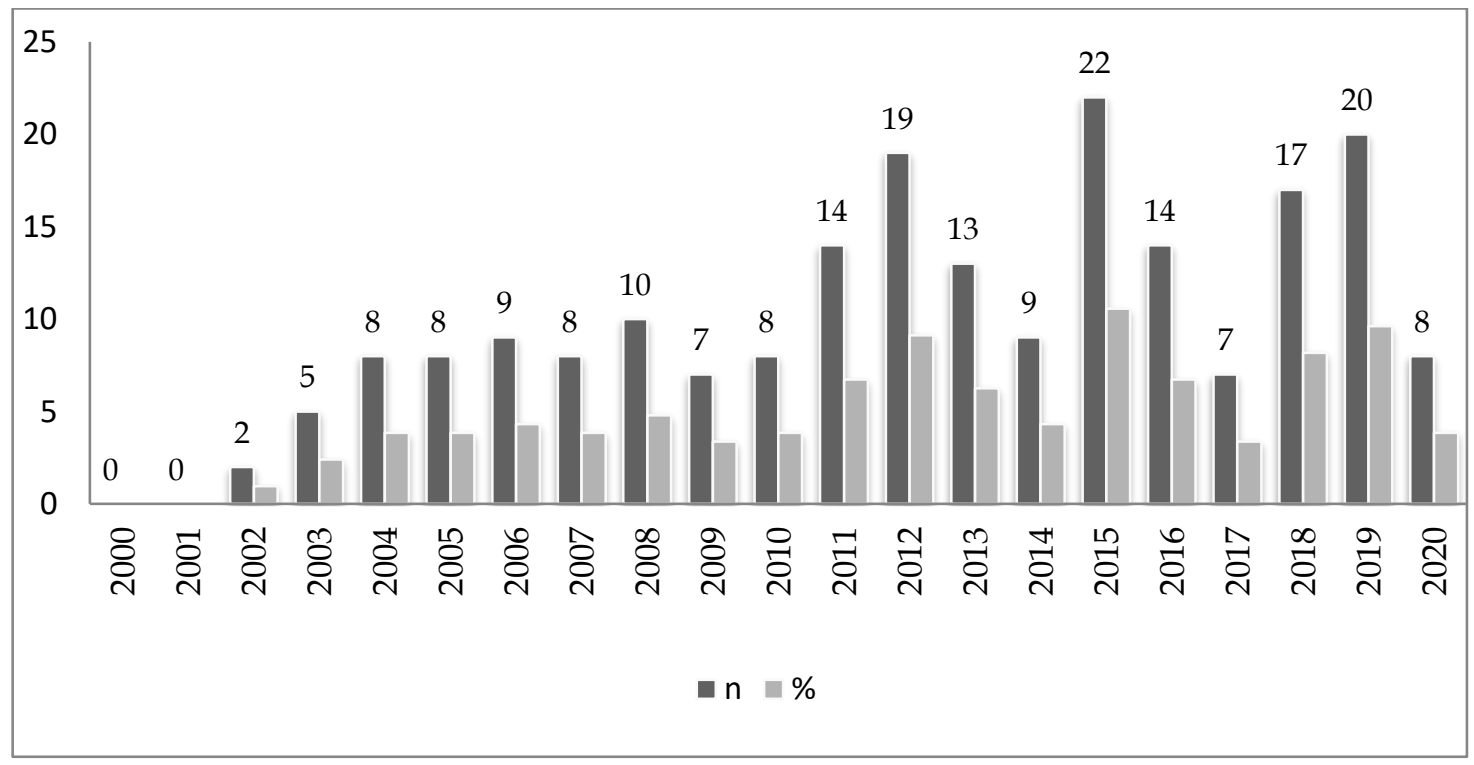

Şekil 2. Öğretmenlik Mesleki Yeterlik Çalışmalarının Yayınlandıklara Yıllara Göre Analizi

Şekil 2 incelendiğinde 2000 ve 2001 yıllarında hiç çalışma yapılmadığı görülmektedir. 2002 yılında başlayan çalışmaların her geçen yıl daha fazlası yapıldığı görülmüştür. 2003, 2004, 2005, 2006, 2007, 2009, 2010, 2014, 2017 ve 2020 yıllarında çalışmalar yapılsa da $(n=10)$ altında olduğu görülmüştür. 2015 yılında 22 çalışma ile en fazla çalışmanın yapıldığı görülmektedir, 2019 yılında 
yapılan 20 çalışma 2015 yılını takip etmektedir. Yapılan 19 çalışma ile 2012 yılı üçüncü sırada yer almaktadır. 2008, 2011, 2013, 2016, ve 2018 yıllarında 10 ve üzeri çalışma yapıldığı görülmüştür.

2000-2020 yılları arasında yayınlanan öğretmen mesleki yeterlik çalışmalarının yayın türüne göre analizi:

Tablo 1.

Öğretmen Mesleki Yeterlik Çalışmalarının Yayın Türüne Göre Analizi

\begin{tabular}{lcc}
\hline Yayın Türü & $\mathbf{n}$ & $\mathbf{\%}$ \\
\hline Makale & 144 & 69.23 \\
Bildiri & 34 & 16.34 \\
Yüksek Lisans Tezi & 26 & 12.50 \\
Doktora Tezi & 4 & 1.92 \\
\hline Toplam & $\mathbf{2 0 8}$ & $\mathbf{1 0 0}$ \\
\hline
\end{tabular}

Tablo 1 incelendiğinde 2000-2020 yılları arasında öğretmen yeterlikleri alanında yapılan toplam 208 çalışmadan; 144 çalışmanın makale alanında, 34 çalışmanın bildiri şeklinde, 26 çalışmanın yüksek lisans tezi olarak, 4 çalışmanın da doktora tezi olarak yapıldığı görülmektedir.

Öğretmenlerin mesleki yeterlikleri ile ilgili çalışmaların örneklem gruplarına göre analizi:

Tablo 2.

Öğretmen Mesleki Yeterlik Çalışmalarının Örneklem Grubuna Göre Analizi

\begin{tabular}{lcc}
\hline Örneklem Grubu & $\mathbf{n}$ & $\mathbf{0}$ \\
\hline Öğretmen & 148 & 71.15 \\
Öğretmen Adayı & 60 & 28.85 \\
\hline Toplam & $\mathbf{2 0 8}$ & $\mathbf{1 0 0}$ \\
\hline
\end{tabular}

Tablo 2 incelendiğinde öğretmen mesleki yeterlikleri ile ilgili yapılan çalışmalardan 148 çalışmanın öğretmenler ile yapıldığı, 54 çalışmanın öğretmen adayları ile yapıldığı, 6 çalışmanın literatür tarama çalışması olarak yapıldığı görülmektedir.

2000-2020 yılları arasında yayınlanan öğretmen mesleki yeterlik çalışmalarının branşlara göre analizi: 


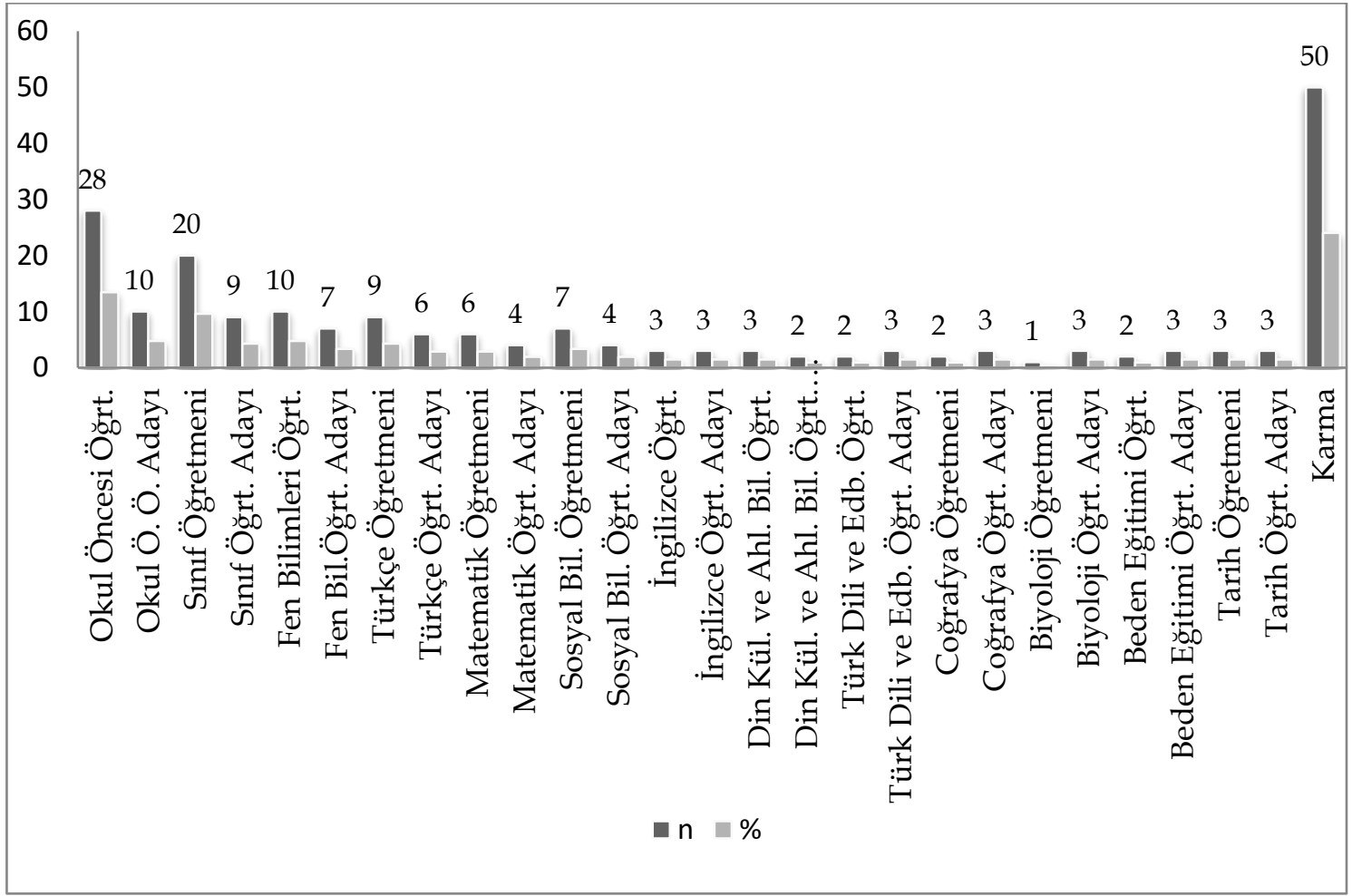

Şekil 3. Öğretmen Mesleki Yeterlik Çalışmalarının Branşlara Göre Dağılımı

Şekil 3 incelendiğinde öğretmen ve öğretmen adayları ile yapılan çalışmaların 50 çalışma ile en fazla karma olarak yapıldığı, 38 çalışma ile okul öncesi ve 29 çalışma ile sınıf öğretmenliği branşları ile çalışıldığı görülmüştür. Fen bilimleri branşında 17 çalışma, Türkçe branşında 15 çalışma, sosyal bilgiler branşında 11 çalışma, matematik branşında 10 çalışma yapıldığı görülmektedir. İngilizce ve tarih branşlarında 6'şar çalışma, din kültürü ve ahlak bilgisi, türk dili ve edebiyatı, beden eğitimi branşlarında $(n=5)$, coğrafya ve biyoloji branşlarında $4^{\prime}$ er çalışma yapıldığı görülmektedir.

2000-2020 yılları arasında yayınlanan öğretmen mesleki yeterlik çalışmalarının konulara göre analizi:

Tablo 3.

Öğretmen Mesleki Yeterlik Çalışmalarının Konu Dağılımlarına Göre Analizi

\begin{tabular}{lcc}
\hline Konu & $\mathbf{n}$ & $\mathbf{\%}$ \\
\hline Öğretmen Yeterlilĭği & 27 & 12.98 \\
Mesleki Yeterlilik İnceleme & 25 & 12.01 \\
Mesleki Yeterlilik Algısı & 32 & 15.38 \\
Ölçek Geliştirme & 15 & 7.21 \\
Mesleki Yeterlik Duygusu & 6 & 2.88 \\
Bilgisayar ve Teknoloji Kullanımı & 10 & 4.80 \\
Bilgi ve İletişim & 6 & 2.88 \\
Kaynaştırma Eğitimi & 7 & 3.36 \\
Pedagojik Bilgi & 6 & 2.88 \\
Din Öğretimi & 6 & 2.88 \\
\hline
\end{tabular}


Tablo 3 (Devam)

\begin{tabular}{lcc}
\hline Mesleki Doyum & 7 & 3.36 \\
Mesleki Gelişim ve Yeterlilik & 7 & 3.36 \\
Kişilik Özellikleri & 4 & 1.92 \\
Drama Eğitimi & 5 & 2.40 \\
Araç Gerȩ̧ Kullanımı & 6 & 2.88 \\
Müzik Eğitimi & 4 & 1.92 \\
Ölçme Değerlendirme & 4 & 1.92 \\
Alan Eğitimi & 3 & 1.44 \\
Öğretim Yöntem ve Teknikleri & 5 & 2.40 \\
Yapılandırmacı Öğrenme & 3 & 1.44 \\
FATïH Projesi & 3 & 1.44 \\
Rehberlik Uygulaması & 2 & 0.96 \\
Kendini Değerlendirme & 2 & 0.96 \\
Eğitsel Oyunlar & 1 & 0.48 \\
Çok Kültürlü Eğitim & 1 & 0.48 \\
Eğitim Programı Okuryazarlığı & 1 & 0.48 \\
Eğitim Yazılımı Seçme & 1 & 0.48 \\
Bilişsel Koçluk Yaklaşımı & 1 & 0.48 \\
Mekansal Biliş & 1 & 0.48 \\
Modelleme & 1 & 0.48 \\
Fen Eğitimi & 1 & 0.48 \\
AB Uyum Süreci & 1 & 0.48 \\
Lider Öğretmenler & 1 & 0.48 \\
Değerler Eğitimi & 1 & 0.48 \\
Bilişsel Araştırma İnceleme & 1 & 0.48 \\
Kimya Programı & 1 & 0.48 \\
\hline Toplam & $\mathbf{2 0 8}$ & $\mathbf{1 0 0}$ \\
\hline
\end{tabular}

Tablo 3 incelendiğinde öğretmen mesleki yeterlikleri konusunda yapılan çalışmalar kategorize edilmiştir. Bu kategorilerde mesleki yeterlik algısı 32 çalışma ile en fazla çalışılan konudur. 27 çalışma ile öğretmen yeterlikleri alanında yapılan çalışmalar ikinci sıradadır. 25 çalışma ile mesleki yeterlik inceleme çalışmaları üçüncü sıradadır. Ölçek geliştirme konusunda 15 çalışma yapılmıştır. Bilgisayar ve teknoloji kullanımı konusunda 10 çalışma yapılmıştır. Kaynaştırma eğitimi, mesleki doyum, meslekli gelişim ve yeterlik konularında 7'şer çalışma yapılmıştır. Mesleki yeterlik duygusu, bilgi ve iletişim, pedagojik bilgi, din öğretimi, araç gereç kullanımı konularında 6'şar çalışma yapılmıştır. Drama Eğitimi, öğretim yöntem ve teknikleri konularında 5'şer çalışma yapılmıştır. Kişilik özellikleri, müzik eğitimi, ölçme değerlendirme konularında 4'er çalışma yapılmıştır. Alan eğitimi, yapılandırmacı yaklaşım, FATïH Projesi konularında 3'er çalışma yapılmıştır. Rehberlik ve kendini değerlendirme konularında 2'şer çalışma yapılmıştır. Eğitsel oyunlar, çok kültürlü eğitim, eğitim programı okuryazarlı̆̆ı, eğitim yazılımı seçme, bilişsel koçluk yaklaşımı, mekansal biliş, modelleme, fen eğitimi, AB Uyum süreci, lider öğretmen, değerler eğitimi, bilişsel araştırma inceleme ve kimya programı konularında 1'er çalışma yapılmıştır.

Elde edilen bulgular incelendiğinde öğretmenlerin öğretmen yeterlikleri kapsamında teknoloji ve teknoloji kullanımı konularında çok sayıda çalışma yapıldığı görülmüştür. 
2000-2020 yılları arasında yayınlanan öğretmen mesleki yeterlik çalışmalarının çalışma yöntemine göre analizi:

Tablo 4.

Öğretmen Mesleki Yeterlik Çalışmalarının Çalışma Yöntemlerine Göre Analizi

\begin{tabular}{lccc}
\hline Yöntem & Model-Desen & $\mathbf{n}$ & $\mathbf{0}$ \\
\hline \multirow{2}{*}{ Nicel } & Tarama & 120 & 64.17 \\
& Deneysel & 18 & 9.62 \\
\multirow{2}{*}{ Nitel } & İlişkisel & 16 & 8.55 \\
\cline { 2 - 4 } Karma & Durum Çalışması & 9 & 4.81 \\
\hline Toplam & Olgubilim & 8 & 4.27 \\
\hline \multicolumn{1}{c}{ Tablo 4 incelendiŏinde öğretmen mesleki yeterlikleri ile ilgili yapılan çalıs̆malarda yöntem }
\end{tabular}

Tablo 4 incelendiğinde öğretmen mesleki yeterlikleri ile ilgili yapılan çalışmalarda yöntem olarak 154 çalışmada nicel yöntem,17 çalışmada nitel yöntem, 16 çalışmada karma yöntem kullanıldığı görülmektedir.

2000-2020 yılları arasında yayınlanan öğretmen mesleki yeterlik çalışmalarının veri toplama araçlarına göre analizi:

Tablo 5.

Öğretmen Mesleki Yeterlik Çalışmalarının Veri Toplama Araçlarına Göre Analizi

\begin{tabular}{|c|c|c|}
\hline Veri Toplam Aracı & $\mathbf{n}$ & $\%$ \\
\hline Ölçek & 110 & 52.88 \\
\hline Anket & 47 & 22.59 \\
\hline Görüşme/Mülakat & 21 & 10.09 \\
\hline Başarı Testi & 13 & 6.25 \\
\hline Gözlem & 9 & 4.32 \\
\hline Doküman İnceleme & 6 & 2.88 \\
\hline Değerlendirme Formu & 1 & 0.48 \\
\hline Öz-Değerlendirme & 1 & 0.48 \\
\hline
\end{tabular}

Tablo 5 incelendiğinde öğretmen mesleki yeterlikleri ile ilgili yapılan çalışmalarda veri toplama aracı olarak en fazla 110 çalışma ile ölçek, 47 çalışma ile anket, 21 çalışma ile de görüşme/mülakat tercih edildiği görülmüştür. Başarı testi 13, gözlem 9, doküman inceleme 6 , değerlendirme formu 1 ve öz değerlendirme formu 1'er defa kullanılan araçlardandır.

Teknolojik Pedagojik Alan Bilgisine Yönelik Bulgular

2000-2020 yılları arasında yayınlanan teknolojik pedagojik alan bilgisi çalışmalarının yayınlandıkları yıllara göre analizi: 


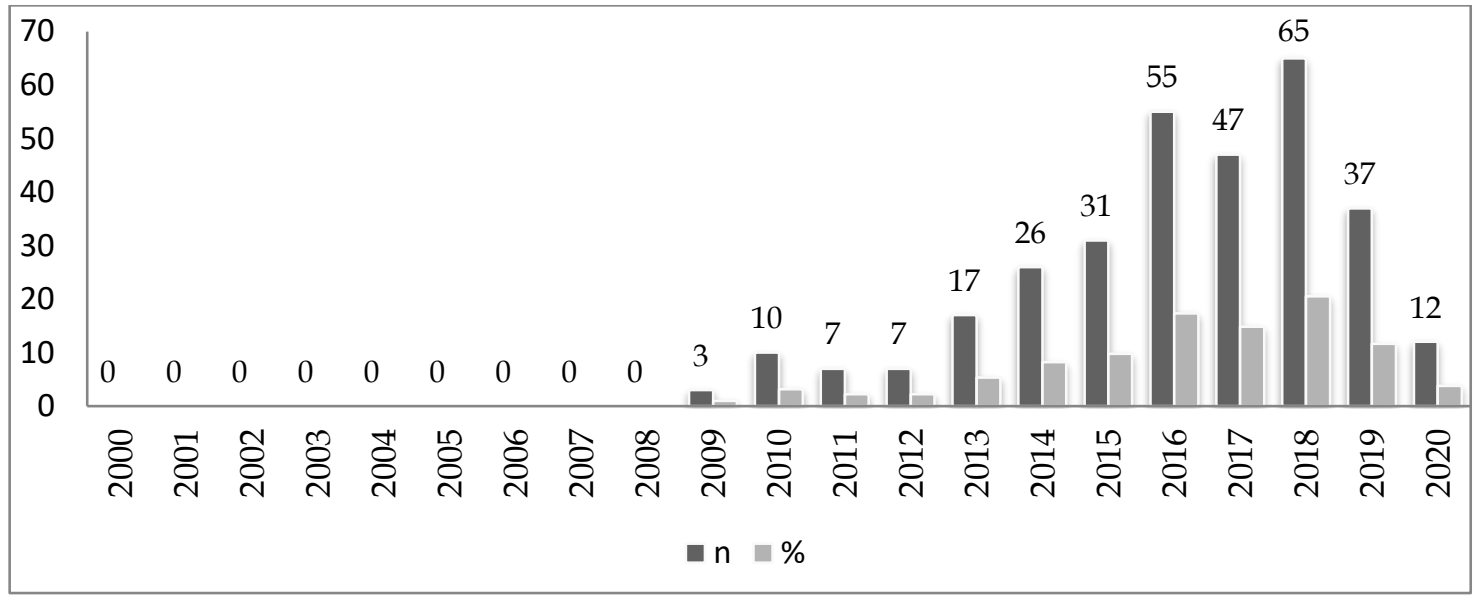

Şekil 4. Teknolojik Pedagojik Alan Bilgisi Çalışmalarının Yayınlandıklara Yıllara Göre Analizi

Şekil 4 incelendiğinde 2000-2020 yılları arasında teknolojik pedagojik alan bilgisine yönelik çalışmaların yıllara göre dağılımına bakıldığında 2000-2008 yılları arasında hiç çalışma yapılmadığı görülmüştür. En fazla çalışmanın 65 çalışma ile 2018 yılında olduğu görülmektedir. 2018 yılını 55 çalışma ile 2016 yılı takip etmektedir. Üçüncü sırada ise 47 çalışma ile 2017 yılındaki çalışmalar vardır. 2019 yılında 37 çalışma, 2015 yılında 31 çalışma, 2014 yılında 26 çalışma, 2013 yılında 17 çalışma, 2020 yılında 12 çalışma, 2010 yılında 10 çalışma, 2011 ve 2012 yıllarında 7'şer çalışma ve 2009 yılında yapılan 3 çalışma ile toplam 317 çalışma yapılmıştır.

2000-2020 yılları arasında yayınlanan teknolojik pedagojik alan bilgisi çalışmalarının yayın türüne göre analizi:

Tablo 6 .

Teknolojik Pedagojik Alan Bilgisi Çalışmalarının Yayın Türüne Göre Analizi

\begin{tabular}{lcc}
\hline Yayın Türü & f & \% \\
\hline Makale & 188 & 59.30 \\
Bildiri & 86 & 27.12 \\
Yüksek Lisans Tezi & 32 & 10.09 \\
Doktora Tezi & 11 & 3.47 \\
\hline Toplam & $\mathbf{3 1 7}$ & $\mathbf{1 0 0}$ \\
\hline
\end{tabular}

Tablo 6 incelendiğinde 2000-2020 yılları arasında çalışılan 317 teknolojik pedagojik alan bilgisi çalışmasından 188 çalışma makale türünde, 86 çalışma bildiri türünde. 32 çalışma yüksek lisans seviyesinde tez olarak, 11 çalışma doktora seviyesinde tez türünde çalışılmıştır.

Teknolojik pedagojik alan bilgisi ile ilgili çalışmaların örneklem grupları açısından incelendiğinde aşağıdaki sonuçlara ulaşılmıştır.

2000-2020 yılları arasında yayınlanan teknolojik pedagojik alan bilgisi çalışmalarının örneklem grubuna göre analizi: 
Tablo 7.

Teknolojik Pedagojik Alan Bilgisi Çalışmalarının Örneklem Grubuna Göre Analizi

\begin{tabular}{lcc}
\hline Örneklem Grubu & $\mathbf{n}$ & $\mathbf{\%}$ \\
\hline Öğretmen & 137 & 43.21 \\
Öğretmen Adayı & 152 & 47.94 \\
Öğrenci & 19 & 5.99 \\
Öğretim Görevlisi & 9 & 2.83 \\
\hline Toplam & $\mathbf{3 1 7}$ & $\mathbf{1 0 0}$
\end{tabular}

Tablo 7 incelendiğinde teknolojik pedagojik alan bilgisi konusunda yapılan çalışmaların

137 çalışmanın öğretmenler ile yapıldığı, 152 çalışmanın öğretmen adayları ile yapıldığı, 19 çalışmanın öğrenciler ile yapıldığı, 9 çalışmanın öğretim elemanları ile yapıldığı görülmüştür. TPAB konusunda 9 ölçek geliştirme çalışmasının yapıldığı ve 6 literatür tarama çalışmasının yapıldığı görülmüştür.

2000-2020 yılları arasında yayınlanan teknolojik pedagojik alan bilgisi çalışmalarının branşlara göre analizi:

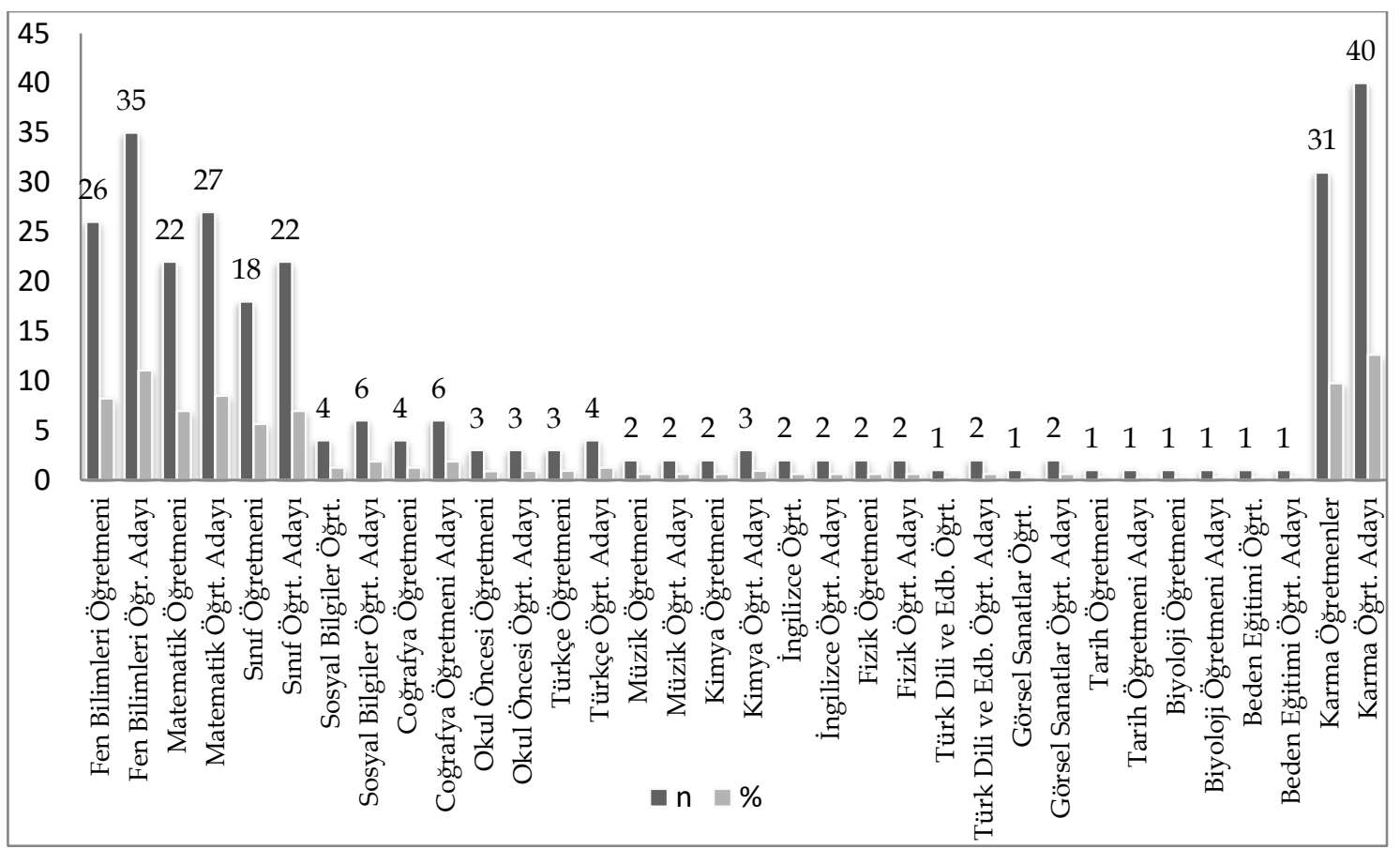

Şekil 5. Teknolojik Pedagojik Alan Bilgisi Çalışmalarının Branşlara Göre Analizi

Şekil 5 incelendiğinde TPAB konusunda yapılan çalışmaların en fazla 71 çalışma ile bütün branşların bir arada olduğu öğretmen ve öğretmen adayları ile yapıldığı görülmektedir. Öğretmenlerin branş bazında bakıldığında ise en fazla çalışmanın 61 çalışma ile fen bilimleri, 49 çalışma ile matematik ve 40 çalışma ile sınıf öğretmenliği branşlarında öğretmen ve öğretmen adayları ile yapıldığı görülmektedir. Bu branşlarda çalışılan öğretmen ve öğretmen adaylarının oranları benzerdir. Diğer branşlarda ise sırasıyla sosyal bilgiler, coğrafya, Türkçe, okul öncesi ve 
kimya alanında çalışma sayısı fazla iken tarih, biyoloji ve beden eğitimi branşlarında ikişer çalışma yapılmıştır.

2000-2020 yılları arasında yayınlanan teknolojik pedagojik alan bilgisi çalışmalarının konulara göre analizi:

Tablo 8.

Teknolojik Pedagojik Alan Bilgisi Çalışmalarının Konulara Göre Analizi

\begin{tabular}{lcc}
\hline Konu & $\mathbf{n}$ & $\mathbf{\%}$ \\
\hline TPAB Düzeyi & 77 & 24.29 \\
TBAP Yeterlilik & 33 & 10.41 \\
Sinıf İi Uygulama & 31 & 9.77 \\
TPAB Öz-yeterlik & 21 & 6.62 \\
Özgüven & 26 & 8.20 \\
Değişkenler & 22 & 6.94 \\
Alg1 & 18 & 5.67 \\
Tutum & 15 & 4.73 \\
Teknoloji Entegrasyonu & 12 & 3.78 \\
Hizmet İçi Eğitim & 8 & 2.52 \\
Ölçme Değerlendirme & 7 & 2.20 \\
Pedagojik Formasyon & 7 & 2.20 \\
Öğrenme Stratejisi & 7 & 2.20 \\
FATïH Projesi & 5 & 1.57 \\
Öz-Değerlendirme & 5 & 1.57 \\
Web.2 Araçları & 4 & 1.26 \\
Hazır bulunuşluk & 3 & 0.94 \\
Düşünme Stili & 3 & 0.94 \\
EBA Kullanımı & 3 & 0.94 \\
Yenilikçi Ö̆ğrenme & 1 & 0.31 \\
Tükenmişlik & 1 & 0.31 \\
Ders Planı & 1 & 0.31 \\
Yaşam Boyu Ö̆ğrenme & 1 & 0.31 \\
Öğretmen Yapısı & 1 & 0.31 \\
\hline Toplam & 317 & $\mathbf{1 0 0}$ \\
\hline
\end{tabular}

Tablo 8 incelendiğinde TPAB ile çalışılan konular kategorize edilmiştir. Çalışılan konulara bakıldığında en fazla çalışılan konular 77 çalışma ile TPAB düzeyleri ve 33 çalışma ile TPAB yeterliliği olmuştur. ТРАВ sınıf içi uygulamaları, ТРАВ öz-yeterliliği, özgüven ve farklı değişkenler (yaş, cinsiyet, öğrenim durumu gibi), algı, tutum ve teknoloji entegrasyonu çok çalışılan konulardır. Bununla birlikte hazır bulunuşluk, düşünme stili, EBA kullanımı, yenilikçi öğrenme, tükenmişlik, ders planı yapma, yaşam boyu öğrenme, öğretmen yapısı konularında daha az çalışma yapılmıştır.

Araştırma bulgularına bakıldığında TPAB'a yönelik çalışmaların büyük çoğunluluğun öğretmen yeterlilikleri kapsamında öğretmen ve öğretmen adaylarının TPAB düzeyleri ve yeterlilikleri konularında çalışıldığı görülmektedir.

2000-2020 yılları arasında yayınlanan teknolojik pedagojik alan bilgisi çalışmalarının çalışma yöntemlerine göre analizi: 
Tablo 9.

Teknolojik Pedagojik Alan Bilgisi Çalışmalarının Yöntemlerine Göre Analizi

\begin{tabular}{lccc}
\hline Yöntem & Model-Desen & $\mathbf{n}$ & $\mathbf{0}$ \\
\hline \multirow{3}{*}{ Nicel } & Tarama & 134 & 42.27 \\
& Deneysel & 42 & 13.24 \\
\multirow{2}{*}{ Nitel } & İlişkisel & 30 & 9.46 \\
\cline { 2 - 4 } Karma & Durum Çalişmasi & 28 & 8.83 \\
Toplam & Olgubilim & 9 & 2.83 \\
\cline { 2 - 4 } & & $\mathbf{7 4}$ & 23.34 \\
\hline
\end{tabular}

Tablo 9 incelendiğinde teknolojik pedagojik alan bilgisi ile ilgili yapılan çalışmalarda yöntem olarak 206 çalışma ile nicel yöntem, 37 çalışma ile nitel yöntem, 74 çalışma ile de karma yöntem kullanıldığı görülmektedir.

2000-2020 yılları arasında yayınlanan teknolojik pedagojik alan bilgisi çalışmalarının veri toplama araçlarına göre analizi:

Tablo 10.

Teknolojik Pedagojik Alan Bilgisi Çalışmalarının Veri Toplama Araçlarına Göre Analizi

\begin{tabular}{lcc}
\hline Veri Toplam Aracı & $\mathbf{n}$ & $\%$ \\
\hline Ölçek & 92 & 29.02 \\
Anket & 74 & 23.34 \\
Görüşme/Mülakat & 44 & 13.88 \\
Gözlem & 38 & 11.98 \\
Başarı Testi & 34 & 10.72 \\
Kontrol Listesi & 15 & 4.73 \\
Doküman İnceleme & 6 & 1.89 \\
Performans Testi & 4 & 1.26 \\
Diğer & 7 & 2.20 \\
\hline Toplam & $\mathbf{3 1 7}$ & $\mathbf{1 0 0}$ \\
\hline
\end{tabular}

Tablo 10 incelendiğinde teknolojik pedagojik alan bilgisi ile ilgili yapılan çalışmalarda veri toplama aracı olarak 92 çalışma ile en fazla ölçek, 74 çalışma ile anket, 44 çalışma ile de görüşme/mülakat tercih edildiği görülmüştür. Gözlem 38, başarı testi 34, kontrol listesi 15, doküman inceleme 6, performans testi 4 ve diğer 7 defa veri toplama aracı olarak kullanılan araçlardandır.

\section{TARTIŞMA}

2000-2020 yılları arasında Türkiye'de yapılan öğretmen mesleki yeterlikleri ve teknolojik pedagojik alan bilgisi konularında yayınlanmış olan çalışmaların yıl, yayın türü, konu alanı, örneklem grubu, araştırmanın uygulandığı branşlar, yöntem ve veri toplama araçları açısından doküman analizi yapılmış olup elde edilen veriler neticesinde ortaya çıan durumlar tartışılmıştır.

Bulgular incelendiğinde öğretmen mesleki yeterlikleri konusundaki çalışmaların, 2002 yılından itibaren başladığı görülmektedir. Çalışmaların 2002 yılında başlamasının sebebi 
“öğretmen yeterlikleri” belgesinin 2002 yllında yürürlüğe girmesidir. 2002 yllından itibaren öğretmen yeterlikleri konusundaki çalışmalar artarak devam etmiştir. Bu konudaki en fazla çalışma 2015 yılında yapılmıştır. 2006, 2012, 2015, 2018 ve 2019 yıllarında çok sayıda çalışma yapıldığı görülmektedir. Bu yıllardaki artışta güncellenen “Öğretmenlik Mesleği Genel Yeterlikleri" belgesinin ve program değişiklilerinin etkisi olabilir (Kazu ve Çam, 2019).

Öğretmen yeterlikleri ile ilgili yapılan çalışmaların türüne bakıldığında en fazla çalışmanın makale türünde olduğu görülmektedir. En az çalışmanın ise doktora düzeyinde tez çalışması olduğu görülmektedir. Ayaz, Oral ve Söylemez (2015) ve Gündoğdu, Aytaçlı, Aydoğan ve Yıldırım (2015) yaptıkları çalışmalarda benzer sonuçlara ulaşmışlardır.

Öğretmen yeterlikleri ile ilgili çalışmalardaki örneklem seçimine bakıldığında öğretmen ve öğretmen adayları ile çalışmalar yapıldığı görülmektedir. Ayaz vd. (2015) ile Gündoğdu vd. (2015) yaptıkları çalışmalarda daha çok öğretmenlerle araştırma yapıldığını belirtmektedir. Öğretmen branşlarına bakıldığında en fazla çalışma branşların birlikte çalışıldığı karma olarak yapılan çalışmalardan sonra okul öncesi branşı ve sınıf öğretmenliği branşında yapıldığı görülmektedir. Gündoğdu ve arkadaşları (2015) da benzer sonuçlara ulaşmıştır.

Öğretmen mesleki yeterlikleri ile ilgili çalışmaların konu dağılımı incelendiğinde öğretmen yeterliği, öğretmenlerin mesleki yeterlikleri ve mesleki yeterlik algısı üzerine çok sayıda çalışma yapıldığı görülmektedir. Çelik, Yorulmaz ve Çokçalışkan (2019) da yaptıkları çalışmada benzer sonuçlara ulaşmıştır. Özellikle 2005-2006 öğretim yılından itibaren öğretim programlarında temel yaklaşım olarak benimsenen yapılandırmacılık sebebi ile öğretmenlerin mesleki yeterlikleri ve öz-yeterlik algıları konularında birçok araştırma yapılmıştır. Tosuntaş, (2020) de yaptığı çalışmada benzer sonuçlara ulaşmıştır. Ayrıca öğretmen yeterlikleri kapsamında teknoloji kullanımı, araç gereç kullanımı, pedagojik bilgi, yapılandırmacı öğrenme, FATïH projesi, kaynaştırma eğitimi, öğretim yöntem ve teknikleri, kişilik özellikleri, sınıf yönetimi, drama, ölçme değerlendirme, mesleki doyum, bilgi ve iletişim, rehberlik uygulamaları gibi birçok konuda çalışma yapılmıştır. Çelik vd. (2019) ile Kazu ve Çam (2019) da yaptıkları çalışmalarda benzer konulardan bahsetmişlerdir.

Öğretmen mesleki yeterlikleri ile ve TPAB'la ilgili çalışmalarda yöntem olarak en fazla nicel yöntem kullanıldığı görülmüştür. Nicel yöntemin bu çalışmalarda karma yöntem ve nitel yönteme göre çok fazla kullanıldığı görülmüştür. Gündoğdu vd. (2015), Kaşkaya (2012), Keser ve Düzkantar (2019) ile Kurtoğlu ve Seferoğlu (2013) da yaptığı çalışmalarda benzer sonuçlara ulaşmıştır. Nicel yöntem kullanılarak yapılan çalışmalarda tarama, deneysel ve ilişkisel desenlemeler kullanılmıştır. En çok kullanılan desen tarama desenidir. Tarama modelinde anket ile çok sayıda verinin kısa zamanda toplanabilme kolaylığı araştırmacıları bu yönteme sevketmiş olabilir. Nitel yöntem kullanılarak yapılan çalışmalarda ise durum çalışması ve olgu bilim deseni kullanılmıştır. Gündoğdu vd. (2015), Keser ve Kantar (2019) ile Kurtoğlu ve Seferoğlu (2013) 
yaptıkları çalışmalarda benzer sonuçlara ulaşmıştır. TPAB araştırmalarında da en az nitel yaklaşım tercih edilmiştir. Kaleli Yılmaz (2015) ile Korucu (2017) benzer sonuçlara ulaşmışlardır.

Öğretmen yeterlikleri ve TPAB'la ilgili çalışmalarda veri toplama aracı olarak çoğunlukla ölçek, anket ve görüşme/mülakat kullanılmıştır. Dikmen ve Demirer (2016) benzer sonuçlara ulaşmıştır. En sık kullanılan yaklaşımın nicel olduğu ve tarama modeli olduğu bulgusu ile tutarlı şekilde veri toplama aracı olarak anket ve ölçeklerin en sık kullanılması beklenen bir durumdur. Daha önceki araştırma sonuçları da bu yöndedir (Gündoğdu vd., 2015; Kaleli Yılmaz, 2015; Kaşkaya, 2012; Korucu vd, 2017; Kurtoğlu ve Seferoğlu, 2013).

Teknolojik pedagojik alan bilgisi konusunda yapılan çalışmalar Türkiye'de 2009 yılından itibaren artarak devam etmiştir. Özellikle 2014 yılından itibaren çok sayıda çalışma yapılmıştır. TPAB henüz 2005 yılında alan yazına girmiş olmasına rağmen sıklıkla kullanılan bir konu olmuştur (Baran ve Bilici, 2015; Dikmen ve Demirer, 2016; Korucu, Usta ve Altun, 2017). Literatürdeki değişim ve yeniliklerin araştırmacılarca takip edildiği ve güncel konularda araştırmalara eğilimin olduğu söylenebilir.

TPAB ile ilgili çalışmaların türüne bakıldığında en fazla çalışma makale türünde yapılmıştır. Bildiri, yüksek lisans tezi ve doktora tez çalışması olarak ta çalışılmıştır. Dikmen ve Demirer (2016) ile Korucu vd. (2017) yaptıkları çalışmada benzer sonuçlara ulaşmışlardır. Lisansüstü tezlerin yayın şartı olarak birçok üniversitede makale ve bildiri isteniyor olması bu durumun sebebi olabilir. Ayrıca bildiri ve makaleler daha kısa süreli sonuçlanan çalışmalarken tez uzun soluklu ve kapsamlı bir araştırmadır. Ulaşılan makale ve bildirilerin de tezlerden üretilen ürünler olması muhtemeldir.

TPAB ile ilgili çalışmaların örneklem seçimine bakıldığında öğretmen, öğretmen adayları, öğrenciler ve öğretim görevlileri ile çalışmalar yapıldığı görülmektedir. En fazla çalışmanın öğretmen adayları ile yapıldığı görülmektedir. Dikmen ve Demirer (2016) ile Korucu vd. (2017) de yaptıkları çalışmada aynı sonuçlara ulaşmışlardır. Yapılan çalışmalara branş bazında bakıldığında en fazla yapılan çalışma branşların bir arada olduğu karma olarak yapılan çalışmalardan sonra fen bilimleri öğretmenleri ve matematik öğretmenleri ile yapıldığı sonucuna ulaşılmıştır. Sınıf öğretmenleri ile de fazla sayıda çalışma yapılmıştır. Baran ve Bilici (2015) ile Korucu vd. (2017) yaptıkları çalışmada TPAB konusunda en fazla çalışmanın öğretmen adayları ile yapıldığını belirtmiştir. Meslek öncesi eğitimde olan öğretmen adaylarının TPAB bakımından potansiyellerini keşfedebilmeleri ve donanımlı olarak yetiştirilmesi adına araştırmalarda örneklem olarak seçilmeleri, araştırmacıların kolay ulaşılabilir örneklem seçim yöntemini tercih etmeleri bu durumun sebebi olabilir. Az sayıda da olsa öğrenciler ve öğretim görevlileri ile çalışmalarda yapılmıştır. Korucu vd. (2017) de yaptıkları çalışmada benzer sonuçlara ulaşmışlardır. Branş olarak ise fen bilgisi öğretmenleri ile en çok çalışılmıştır. TPAB, kavramların somutlaştırılması ve öğretimin kolaylaştırılmasında teknoloji kullanımına aracılık rolü gören bir 
bilgi olarak ele alındığında fen ve matematik derslerinde kullanımının daha verimli olduğu düşüncesiyle bu branşlarda daha çok araştırma yapılmış olabilir. Diğer branşlarla kıyaslandığında anlaşılması zor ve soyut kavramlar içeren fen derslerinde teknoloji ve teknoloji destekli öğretim materyal ve yaklaşımlarının kullanımı yaygındır (Dikmen ve Demirer, 2016; Gündoğdu, Aytaçlı, Aydoğan ve Yıldırım, 2015).

TPAB ile ilgili çalışmaların konu dağılımı incelendiğinde en fazla çalışmanın TPAB'ın düzeyleri ve TPAB yeterlikleri alanlarında yapıldığı görülmüştür. Korucu vd. (2017) de yaptıkları çalışmada benzer sonuçlara ulaşmışlardır Chai (2013) ile Wu (2013) yaptıkları çalışmalarda TPAB'nin alandan bağımsız incelendiğini söylemişlerdir. TPAB ayrıca çeşitli değişkenler, özdeğerlendirme, teknoloji entegrasyonu, tutum, sınıf içi uygulama, hizmet içi eğitim, pedagojik formasyon, ölçme değerlendirme, FATIH projesi, hazır bulunuşluk gibi birçok konu ile çalışılmıştır. TPAB ile algı üzerine de birçok çalışma yapılmıştır. Öğretmenlerin TPAB algıları ve öz-güvenleri üzerine de birçok çalışma yapılmıştır. Yapılan araştırmalar neticesinde öğretmenlerin teknoloji kullanımını teorik olarak bildiklerini fakat pratiğe dökemedikleri sonucuna ulaşılmıştır. Ayrıca öğretmenleri teknolojiye karşı olumsuz algılarının TPAB'a da olumsuz yansıdığı sonucuna ulaşılmıştır. Teknolojiye karşı olumlu algı TPAB'a da olumlu yansımaktadır. Bunun yanında teknoloji kullanım öz-güveni düşük olan öğretmenlerin ТРAB kullanımının da düşük olduğu vurgulanmıştır (Kula, 2015; Usta ve Korkmaz, 2010).

\section{SONUÇ}

Öğretmen mesleki yeterlikleri ile ilgili literatür incelendiğinde çalışmaların 2002 yılında başladığı ve en fazla çalışmanın 2015 yılında yapıldığı sonucuna ulaşılmıştır. Yapılan çalışmaların çoğunluğu makale türünde yapılmıştır. Yapılan çalışmalarda en fazla karma olarak yapılan araştırmalardan sonra okul öncesi ve sınıf öğretmenliği branşların da yapılmıştır. Yapılan bu çalışmalarda öğretmen yeterliliği, öğretmen mesleki yeterlik ve öğretmen yeterlik algılarının çoğunlukla çalışıldığı görülmüştür. Yapılan çalışmalarda genellikle nicel yöntem kullanıldığı ve araştırmaların tarama, deneysel ve ilişkisel tarama şeklinde desenlendiği görülmüştür. Nitel olarak tasarlanan çalışmalarda ise durum çalışması ve olgu bilim deseninde çalışmalar yapıldığ görülmüştür. Veri toplama aracı olarak genellikle ölçek, anket, görüşme ve başarı testlerinin kullanıldı̆̆ı görülmüştür. Bunların yanında gözlem, doküman inceleme ve değerlendirme formları da kullanılmıştır.

Teknolojik pedagojik alan bilgisi ile ilgili literatür incelendiğinde çalışmaların 2009 yılında başladığı ve giderek arttığı görülmüştür. Özellikle 2014 yılından itibaren çok sayıda çalışma yapılmıştır. Yapılan çalışmaların çoğunluğu makale türünde yapılmıştır. Yine literatür incelendiğinde daha çok fen bilgisi ve matematik öğretmenleri ile ve bu alanlara ait öğretmen adayları ile çalışmalar yapıldığı görülmüştür. Sınıf öğretmenleri ve sınıf öğretmenliği adaylarına yönelik yapılan çalışmalarında yapıldığı görülmektedir. Yapılan bu çalışmalarda genellikle 
TPAB'ne ilişkin yeterlilikler, TPAB düzeyleri, TPAB sınıf içi uygulamalar, TPAB üzerine alg1 yönünde çalışmalar yapılmıştır. Ayrıca yapılan bu çalışmalarda cinsiyet, kıdem yılı, mezun olunan alan gibi değişkenlere göre incelemeler yapılmış öğretmenlerin teknolojik yeterlilikleri, teknolojiye karşı tutumları ve algıları, TPAB'ne karşı özgüven ve öz-yeterlikleri gibi alanlarda çalışmalar yapıldığı görülmektedir (Kaleli Yılmaz, 2018). Yapılan çalışmalarda genellikle nicel yöntem kullanıldığı ve araştırmaların tarama, deneysel ve ilişkisel tarama şeklinde desenlendiği görülmüştür. Nitel olarak tasarlanan çalışmalarda ise durum çalışması ve olgu bilim deseninde çalışmalar yapıldığı görülmüştür. Veri toplama aracı olarak genellikle ölçek, anket, görüşme ve başarı testlerinin kullanıldığı görülmüştür. Bunların yanında gözlem, kontrol listesi ve performans testi de kullanılmıştır. TPAB' ne yönelik yapılan çalışmaların konularına bakıldığında çoğunlukla öğretmen yeterlikleri kapsamında öğretmenlerin TPAB düzeyleri, TPAB yeterlilikleri TPAB'nin sınıf içi uygulamaları gibi konularda yapıldığı söylenebilir.

\section{ÖNERILER}

Araştırma sonuçları çerçevesinde öğretmen yeterlikleri ve teknolojik pedagojik alan bilgisi konularında yüksek lisans ve doktora tezi olarak daha fazla çalışma yapılabilir. Öğretmenlerin öğrenme ortamlarında öğretim yöntem ve teknikleri kapsamında uyguladıkları teknoji ve teknolojik pedagojik alan bilgilerinin öğrencilerin motivasyon, güdülenme, sınıf içi etkinliklere katılım ve öğrenme anlamında ne derece etkili olduğunun anlaşılabilmesi için öğrenciler ile çalışma yapılması önerilir.

Günümüz dünyasında sosyal, kültürel ve ekonomik alanlarda çok hızlı değişimler olmaktadır. Bu değişimler eğitim ve öğretim alanlarıda bir hayli etkilemektedir. Eğitim ve öğretimi bu değişime hazırlayacak ve uyarlayacak kişiler öğretmenlerimizdir. Bu sebeple öğretmen yeterlikleri ile ilgili konularda yapılan çalışmalardan alınan sonuçlar çerçevesinde hali hazırda çalışan öğretmenlere hangi alanlarda eksiklik tespit edildi ise o alanlarda hizmet içi eğitimler verilebilir. Yeni yetişen öğretmenlerimizi de yapılan araştırmalar neticesinde eğitimler verilerek daha donanımlı ve günümüz şartlarına hazır öğretmenler olarak yetiştirebiliriz.

\section{KAYNAKÇA}

Atmaca, Ç. (2017). İngilizce öğretmenlerinin mesleki kimlik açısından öğretmen yeterlikleri hakkındaki görüşleri. Abant İzzet Baysal Üniversitesi Eğitim Fakültesi Dergisi, 17(4), 16411669.

Ayaz, M., Oral, B., \& Söylemez, M. (2015). Türkiye'de öğretmen eğitimi ile ilgili yapılmış lisansüstü tezlerin değerlendirilmesi. İlköğretim Online, 14(2), 787-802, 2015.

Azgın, A. O. \& Şenler, B. (2018). İlkokullarda görev yapan sınıf öğretmenlerinin teknolojik pedagojik alan bilgilerinin incelenmesi. Journal of Computer and Education Research, 6(11), 47-64. 
Bağdiken, P., \& Akgündüz, D. (2018). Fen bilimleri öğretmenlerinin teknolojik pedagojik alan bilgisi özgüven düzeylerinin incelenmesi. Gazi Eğitim Fakültesi Dergisi, 38(2), 535-566.

Baran, E., \& Canbazoğlu Bilici, S. (2015a). Teknolojik pedagojik alan bilgisi (TPAB) üzerine alanyazın incelemesi: Türkiye örneği. Hacettepe Üniversitesi Eğitim Fakültesi Dergisi, 30(1), 15-32.

Baran, E., \& Canbazoğlu Bilici, S. (2015b). Fen bilimleri öğretmenlerinin teknolojik pedagojik alan bilgisine yönelik öz-yeterlik düzeylerinin incelenmesi: boylamsal bir araştırma. Gazi Üniversitesi Gazi Eğitim Fakültesi Dergisi, 35(2), 285-36.

Başbay, A., \& Bektaş, Y. (2010). Çok kültürlülük bağlamında öğretim ortamı ve öğretmen yeterlikleri. Eğitim ve Bilim, 34(152), 30-43.

Bektaş, M., Ayvaz Can, A., \& Çalıkoğku, E. (2019). Sınıf öğretmeni adaylarının mesleki beceri öğretmen yeterliklerinin incelenmesi. Trakya Ĕ̆itim Dergisi, 9(4), 771-790.

Çelik, Ö., Yorulmaz. A., \& Çokçalışkan. H. (2019). Öğretmen genel yeterlikleri açısından sınıf öğretmenleri ve öğretmen adaylarının kendilerini değerlendirmeleri. Eskişehir Osmangazi Üniversitesi Sosyal Bilimler Dergisi, Nisan 2019, 20(Özel Say1), 203-215.

Cemaloğlu, N. (2014). Türkiye'de okul yöneticisi yetiştirme ve istihdamı var olan durum, gelecekteki olası gelişmeler ve sorunlar. Gazi Eğitim Fakültesi Dergisi, 25(2), 249-274.

Chai, C. S., Koh, J. H. L., \& Tsai, C.-C. (2013). A review of technological pedagogical content knowledge. Journal of Educational Technology \& Society, 16(2), 31-51.

Çoban, Ü. G., Akpınar, E., Baran, B., Sağlam, M., Özcan, E., \& Kahyaoğlu, Y. (2016). Fen bilimleri öğretmenleri için "teknolojik pedagojik alan bilgisi temelli argümantasyon uygulamaları" eğitiminin değerlendirilmesi. Eğitim ve Bilim, 41(188), 1-33.

Dikmen, C., \& Demirer, V. (2016). Türkiye'de teknolojik pedagojik alan bilgisi üzerine 2009-2013 yılları arasında yapılan çalışmalardaki eğilimler. Turkish Journal of Education, 5(1), 33-46.

Garba, S. A., Byabazaire, Y., \& Busthami, A. H. (2015). Toward the use of 21st century teachinglearning approaches: The trend of development in Malaysian schools within the context of Asia Pacific. International Journal of Emerging Technologies in Learning, 10(4), 72-29.

Gönen, S., \& Kocakaya, F. (2015). Pedagojik formasyon programına katılan öğrencilerinin TPAB yeterliklerinin çeşitli değişkenlere göre incelenmesi. Eğitim ve Öğretim Araştırmaları Dergisi, $4(4), 82-90$.

Gündoğdu, K., Aytaçlı, B., Aydoğan, R., \& Yıldırım, C. (2015). Öğretmen yeterlikleri alanında yazılan makalelerin içerik analizi. Adnan Menderes Üniversitesi Eğitim Fakültesi Eğitim Bilimleri Dergisi, 6(2), 30-43.

Gürültü, E., Aslan M., \& Alcı B. (2018). İlköğretim öğretmenlerinin yeterliklerinin 21. yüzyıl becerileri ışığında incelenmesi. The Journal of Academic Social Sciences. 6(71), 543-560. 
Güven, D. (2010). Profesyonel bir meslek olarak türkiye'de öğretmenlik. Boğaziçi Üniversitesi Eğitim Dergisi, 27(2), 13-21.

Kabakçı Yurdakul, I. (2011). Öğretmen adaylarının TPAB yeterliklerinin bilgi ve iletişim teknolojilerini kullanımları açısından incelenmesi. Hacettepe Üniversitesi Journal of Education, 40, 397-408.

Kaleli Yılmaz, G. (2018). Türkiye'deki teknolojik pedagojik alan bilgisi çalışmalarının analizi: bir meta-sentez çalışması. Eğitim ve Bilim, 40(178), 103-122.

Karakoç, B., Turan, E., \& Kevser, K. (2018). Türkiye'de öğretmen yetiştirme konusunda yapılan lisansüstü tezlerin incelenmesi. Akdeniz Eğitim Araştırmaları Dergisi, 12(24), 313-333

Karakuyu, Y., \& Karakuyu, A. (2016). Motivasyon ve öz-yeterliğin sınıf öğretmeni adaylarının teknolojik pedagojik alan bilgilerine (TPAB) katkısı. Uşak Üniversitesi Eğitim Araştırmaları Dergisi, 2(1), 89- 100.

Karalar, H., \& Altan Aslan, B. (2016). Sınıf öğretmeni adaylarının teknolojik pedagojik alan bilgisi yeterliklerin ve öğretmen öz-yeterliklerinin incelenmesi. Cumhuriyet International Journal of Education, 5(5), 15 - 30.

Kaşkaya, A. (2012). Öğretmen yeterlilikleri kapsamında yapılan araştırmaların konu amaç yöntem ve sonuçları açısından incelenmesi. Kuram ve Uygulamada Eğitim Bilimleri, 12(2), 789-805.

Kaya, Z., \& Yılayaz, Ö. (2013). Öğretmen eğitimine teknoloji entegrasyonu modelleri ve teknolojik pedagojik alan bilgisi, Batı Anadolu Eğitim Bilimleri Dergisi, 4(8), 57-83.

Kazu, İ., \& Çam, H. (2019). Öğretmen yeterliği ve nitelikleri üzerine yapılmış lisansüstü çalışmaların incelenmesi: Bir içerik analizi çalişmasi. Elektronik Sosyal Bilimler Dergisi, 18(71), 1349-1367.

Keser, F., \& Düzkantar, A. (2019). Bir alanyazin taraması: “Öğretmen yeterliliklerinin bütünleştirme uygulamalari açısından incelenmesi". Uluslararası Sosyal Araştırmalar Dergisi $12(65), 842-849$.

Koehler, M. \& Mishra, P. (2009). What is technological pedagogical content knowledge (TPACK)? Contemporary Issues in Technology and Teacher Education, 9(1), 60-70.

Korucu, A., Usta, E., \& Handan, A. (2017). Teknolojik pedagojik alan bilgisi üzerine yapılan 20102016 dönemi araştırmalardaki eğilimler. Amasya Üniversitesi Eğitim Fakültesi Dergisi 6(1), 104-133.

Kula, A. (2015). Öğretmen adaylarının teknolojik pedagojik alan bilgisi (TPAB) yeterliliklerinin incelenmesi: Bartın üniversitesi örneği. Akademik Sosyal Araştırmalar Dergisi, 3(2), 395-412.

Kurtoğlu, M., \& Seferoğlu, S. (2013). Öğretmenlerin teknoloji kullanımı ile ilgili türkiye kaynaklı dergilerde yayımlanmış makalelerin incelenmesi. Journal of Instructional Technologies \& Teacher Education, 2(3), 1-10. 
Milli Eğitim Bakanlığı (MEB). (2017). Öğretmen Strateji Belgesi 2017-2023. 17.11.2020 tarihinde www.meb.gov.tr adresinden alındı.

Milli Eğitim Bakanlığı (MEB). (2017). Öğretmenlik mesleği genel yeterlikleri. 17.11.2020 tarihinde www.meb.gov.tr adresinden alındı.

Mishra, P., \& Koehler, M. J. (2006). Technological pedagogical content knowledge: A framework for teacher knowledge. The Teachers College Record, 108(6), 1017-1054.

Öztürk, E. (2013). Sınıf öğretmeni adaylarının teknolojik pedagojik alan bilgilerinin bazı değişkenler açısından değerlendirilmesi. Uşak Üniversitesi Sosyal Bilimler Dergisi, 6(2), 223228.

Pantić, N., \& Wubbels, T. (2010). Teacher competencies as a basis for teacher education - Views of Serbian teachers and teacher educators. Teaching and Teacher Education, 26(3), 694-703.

Seferoğlu, S. S. (2004). “Öğretmen Yeterlilikleri Ve Mesleki Gelişim. Bilim ve Aklın Aydınlığında Eğitim, 58, 40-45.

Shulman, L. S. (1986). Those who understand: Knowledge growth in teaching. Educational Researcher, 15(2), 4-14.

Sönmez, S. (2014). Türk öğretmen yetiştirme (öğretmen okulları) felsefesi. Sakarya Üniversitesi Eğitim Fakültesi Dergisi, 14, 230-239.

Tosuntaş, Ş. B. (2020). Öğretmenlik mesleği genel yeterliklerinin incelenmesi. Akademik Eğitim Bilimleri Dergisi, 4(1), 53-61.

Tuğluk, M., \& Kürkmen, S. (2018). Türkiyede öğretmen yeterlilikleri. Adıyaman Üniversitesi Sosyal Bilimler Enstitüsü Dergisi, 10(30), 809-841.

Usta, E., \& Korkmaz, Ö. (2010). Öğretmen adaylarının bilgisayar yeterlikleri ve teknoloji kullanımına ilişkin algıları ile öğretmenlik mesleğine yönelik tutumları. Uluslararası İnsan Bilimleri Dergisi, 7(1), 1335-1349.

Voogt, J., Fisser, P., Pareja-Roblin, N., Tondeur, J., \& Braak, J. (2013). Technological pedagogical

$\mathrm{Wu}, \mathrm{Y} . \mathrm{T}$. (2013). Research trends in technological pedagogical content knowledge (TPACK) research: A review of empirical studies published in selected journals from 2002 to 2011. British Journal of Educational Technology, 44(3), 73-76.

Yanpar, Y. T., Sancar, T. H., Özgelen, S., \& İncikabı, L. (Eds.), (2013). TPAB - temelli öğretim teknolojileri ve materyal tasarımı dersi: matematik öğretimi için web tabanlı uzaktan eğitim ortamı tasarlama (239-258) içinde, Ankara: Anı Yayıncılık.

Yıldırım, A., \& Şimşek, H. (2016). Sosyal bilimlerde nitel araştırma yöntemleri. Ankara: Seçkin Yayıncilik.

Etik Kurul Kararı: Gerçekleştirilen bu bilimsel çalışma kapsamında herhangi bir canlıdan herhangi bir yolla veri elde edilmediğinden dolayı etik kurul kararına gerek yoktur. 